\title{
Hugh Thomas: fifth time lucky
}

The public health lecturer and GP got into medical school on his fifth attempt, proving that persistence does pay off

\section{Jacqui Wise}

London, UK

\section{Early life}

My earliest ambition was to be a pilot. At school I did arts subjects at A level-geography, history, and economics. I got a Royal Air Force cadetship and they found me a place at Salford University to study the new subject of environmental science. I became interested in public health and resigned my commission—although this meant I had to pay back my education costs of $£ 1000$.

\section{Gaining experience}

I then worked as a public health inspector in Birmingham for two years. During this time, I decided I wanted to become a doctor and did biology and physics $\mathrm{O}$ levels through a correspondence course and A level chemistry at night school. I applied for medical school but didn't get in so improved my qualifications by getting an MSc in Occupational Safety and Hygiene.

\section{Pesticide research}

For the next five years I worked as a research officer at the Medical Research Council epidemiology unit in Cardiff. I wrote quite a few papers on pesticide hazards during this time-some coauthored with Liam Donaldson who went on to become the chief medical officer for England. I shared an office for two years with the late Archie Cochrane who worked there in retirement. He encouraged me to keep trying for medical school and wrote a personal letter supporting my application.

\section{Persistence}

I finally got into medical school on my fifth attempt, after Sir Robert Kilpatrick, dean of Leicester, recognised my name as he had an interest in pesticides and health. I was 29 when I started, the oldest in my year. I already had one child and my second was born while I was studying. I did not get a grant for the first two years of my course but in my third year, when I made my annual phone call to my local authority in Cardiff, I was told, "Oh, it's you again, you may be in luck, we've got some money left over." For the final three years I had a mature student grant and will be forever grateful for the student grant system.

\section{Varied path}

I have not followed the usual career path. I became a registrar in community medicine in Thanet, then a senior house officer in ophthalmology in Swindon. Later I trained as a GP and got a partnership in Eastbourne. I have also written a large number of research papers on public health and occupational health.

\section{Teaching career}

When I was 56, I became a part time lecturer in public health at St George's and combined this with working as a GP part time. I enjoy the balance of clinical practice and teaching about global health. I work with a charity called PHASE (Practical Help Achieving Self Empowerment) and, through this, have made five visits to Nepal to teach and encourage healthcare practitioners. In Nepal you have to go back to your basic clinical skills as you can't send off for diagnostic tests. When you get back it makes you so grateful to the NHS.

\section{Medical mavericks}

I have had a lot of lucky breaks. There have been a many of people who have been kind and supportive. Some doors are labelled "push." The difficulty is knowing how long and how hard to push. I think it is important to have a few mavericks in medical school. It's a shame that nowadays everyone is expected to have all $\mathrm{A}^{*}$ grades in order to get in. Patients want a doctor who can listen to them and relate to them and their struggles in life. I have had the best of both worlds as I have managed to keep up some flying and still have my pilot licence.

\section{Career Timeline}

2009 to date: Senior lecturer in public health and primary care, St George's Medical School, London

2000-2009: GP principal, Eastbourne

1994-1999: Part time consultant epidemiologist, MRC unit, Penarth, South Wales

1993-1996: Clinical assistant in ophthalmology, Salisbury 1990-1993: Senior registrar in public health medicine, Salisbury 1989-1990: Senior house officer, ophthalmology, Swindon 1987-1989: Registrar in community medicine, Canterbury and Thanet Health Authority

1981-1986: University of Leicester medical schoo

1976-1981: Research officer, MRC epidemiology unit, Cardiff 
